\title{
Checklist of polychaetes (Annelida: Polychaeta) from a sandstone reef of Southeastern Brazil
}

\section{Nálita Maria Scamparle Teodoro ${ }^{1}$, Karla Gonçalves da Costa ${ }^{2}$}

${ }^{1}$ Universidade Federal do Espírito Santo. Centro Universitário Norte do Espírito Santo. Departamento de Ciências Agrárias e Biológicas. Laboratório de Genética e Conservação Animal. Rodovia BR-101 Norte, km 60, Litorâneo. São Mateus-ES, Brasil (CEP 29932-540). Email: nalita.scamparle@gmail.com.

${ }^{2}$ Universidade Federal do Espírito Santo. Centro Universitário Norte do Espírito Santo. Departamento de Ciências Agrárias e Biológicas. Laboratório de Ecologia Bentônica. Rodovia BR-101 Norte, km 60, Litorâneo. São Mateus-ES, Brasil (CEP 29932-540).

Abstract. A checklist of polychaetes from a neglected region of Brazil is presented. This is the first study conducted on the sandstone reef of the Urussuquara Beach in the Espírito Santo State, in Southeastern Brazil. The samplings occurred in the intertidal region by through of a quadrat of $30 \mathrm{~cm}$ x $30 \mathrm{~cm}$. Among the 36 polychaete taxa found, the most abundant were Phragmatopoma caudata, Marphysa sanguinea, Perinereis spp., Perinereis anderssoni, and Syllidae type 1 and a zona lower intertidal presented larger abundance. Our study also contributes with new records of four polychaete genus for the Espírito Santo State, Notomastus, Hemipodus, Lysarete, Proceraea and a new species of Syllidae. We hope to promote a better understanding of the sandstone reef's biodiversity, fill the gap that exists in the Espírito Santo State and to contribute as a useful basis for the future elaboration of management and conservation plans for this environment.

Keywords: Consolidated substrate; Intertidal zone; Macrofauna; New records; Urussuquara Beach.

Resumo. Checklist de poliquetas (Annelida: Polychaeta) de um recife de arenito do sudeste do Brasil. Uma lista de verificação de poliquetas de uma região negligenciada do Brasil é apresentada. Este é o primeiro estudo realizado no recife de arenito da praia de Urussuquara, no estado do Espírito Santo, no sudeste do Brasil. As amostragens ocorreram na região intertidal por meio de um quadrat de $30 \mathrm{~cm}$ x $30 \mathrm{~cm}$. Entre os 36 táxons encontrados, os mais abundantes foram: Phragmatopoma caudata, Marphysa sanguinea, Perinereis spp., Perinereis anderssoni e Syllidae tipo 1 e a zona intertidal inferior apresentou maior abundância. Nosso estudo também contribui com novos registros de quatro gêneros de poliquetas para o Estado do Espírito Santo, Notomastus, Hemipodus, Lysarete, Proceraea, bem como uma nova espécie de Syllidae. Esperamos promover uma
Recebido:

04/08/2018

Aceito:

29/08/2018

Publicado:

31/08/2018

Acesso aberto

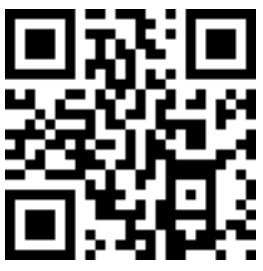

ORCID

(1) 0000-0003-1901-9505

Nálita Maria

Scamparle Teodoro

(D) 0000-0002-8356-4391

Karla Gonçalves da

Costa 
melhor compreensão da biodiversidade dos recifes de arenito, preencher a lacuna que existe no Espírito Santo e contribuir com uma base útil para a elaboração futura de planos de manejo e conservação para este ambiente.

Palavras-chave: Substrato consolidado; Zona intertidal; Macrofauna; Novos registros; Praia de Urussuquara.

\section{Introduction}

Polychaeta is a predominantly marine group whose main characteristic are their numerous bristles distributed by the body emerging from fleshy projections named parapodia. This group presents a high taxonomic diversity, a broad morphological variety, and several feeding strategies, including predation, parasitism, suspension feeding, and debris ingestion (Rouse and Pleijel, 2001). These worms can be pelagic, epibenthic or diggers, occur from the intertidal region to the deep sea, and are found in all regions of the planet, from tropical to polar regions (Rouse and Pleijel, 2001, D'Alessandro et al., 2016). They represent an important group in reef environments and present different lifestyles, can be sessile or free living and inhabit virtually all types of substrate, including unconsolidated sediments such as sand and mud, and consolidated, such as rocky shores and sandstone reefs.

Sandstone reefs are limestone formations resulting from the consolidation of ancient beaches, or from one or more banks of consolidated sand (Correia, 2005). These formations consist of rectilinear rock structures, which are parallel to the coastline and can be uncovered at low tides (Correia and Sovierzoski, 2009). Differ from a typical rocky shore and coral reefs mainly because of their gentle slope and sedimentary composition (Rabelo et al., 2015). These consolidated substrates are formed by the sedimentation of ancient Quaternary sandbanks through chemical reactions with calcium carbonate and are usually arranged along parallel lines to the coast and near the mouths of rivers and estuaries (Correia and Sovierzoski,
2009; Correia, 2010; Padula et al., 2012). Often, these reefs are responsible for the stability of many coastal regions, since they are located in intertidal regions or permanently flooded areas, acting as wave energy sinks, protecting coves, and sometimes forming natural pools (Maia and Cavalcante, 2005).

Likewise rocky shores, sandstone reefs are dynamic habitats and harbor a wide variety of macrofauna, meiofauna and benthic organisms, including benthic algae (Giere, 2009; Sönmez et al., 2014). Also, sandstone reefs provide food and shelter for these organisms and allow their growth and reproduction (Nybakken and Bertness, 2004).

Many of the animals found in this environment live intertwined with marine algae adhered to the substrate, thus constituting the phytal. The algae increase the complexity of the environment and amount of resources for organisms. They also provide a substrate for flora and fauna, thus favoring a milder environment against the action of waves. Thus, the algae contribute to the development of different life forms, consequently raising the biodiversity of the environment (Edgar, 1983; Masunari, 1987; Gao and McKinley, 1994; Spalding et al., 2003; Nascimento and Rosso, 2007).

In Brazil, most of the studies on fauna associated to algae were performed on rocky shores, since these environments are distributed along almost the entire coast, particularly in Southeastern Brazil (Coutinho, 2002). On the other hand, surveys on the benthic fauna of consolidated substrates in the Brazilian coast are still scarce (Coutinho, 2002), including the marine invertebrates of the Espírito Santo State 
in southeastern Brazil, among which species of the Phylum Annelida stand out.

Regarding the marine benthic macrofauna in Brazil, the coasts of the Southern and Southeastern have been the most studied regions, except for the Espírito Santo State in the Southeast (Amaral and Jablonki, 2005). Particularly for Espírito Santo State, most of the few studies conducted so far on its coast are concentrated in the Central and Southern Mesoregions (Nalesso et al., 2005; Costa and Nalesso, 2006; Sá et al., 2007). In the Northern Mesoregion of the Espírito Santo State, although some studies involving benthic macrofauna have been conducted (Scamparle, personal observation), none of them has been published yet.

In this paper, we present the checklist of Polychaeta of Urussuquara sandstone reef and your distribution between three intertidal zones. We emphasize the need to know what is in this ecosystem since studies on sandstone reefs are neglected in relation to other consolidated substrates. Another factor that justifies this work is the construction of the São Mateus Port Center planned for the beginning of 2019, which may extinguish the local fauna causing changes in the fauna of Urussuquara Beach and its surroundings. We hope to promote a better understanding of the sandstone reef's biodiversity, as well as to contribute as a useful basis for the future elaboration of management and conservation plans for this environment.

\section{Materials and methods}

\section{Study area and field sampling}

The study was conducted on a sandstone reef in the Urussuquara Beach $\left(19^{\circ} 04^{\prime} 09^{\prime \prime} \mathrm{S}, 39^{\circ} 43^{\prime} 22^{\prime \prime} \mathrm{W}\right)$, Northern Espirito Santo, Southeastern Brazil, in an area near the mouth of the Ipiranga River, which runs in parallel with the sea (Figure 1). In this place, next year will be installed a port terminal that will burial the reef.

Sampling was performed during low tides on spring tides on August 2010, February 2011, and August 2011. Per sampling period, six replicates were collected in each zone of the intertidal region (lower intertidal, LI; middle intertidal, MI; and upper intertidal, UI). Quadrats $(30 \mathrm{~cm} \quad \mathrm{x} 30 \mathrm{~cm})$ were randomly thrown on algae stains present on the substrate and, from this delimitation, the algae were scraped with a metal spatula.

The collected material was stored in plastic bags, labeled, and fixed in 10\% formaldehyde. Subsequently, the material was taken to the Benthic Ecology Laboratory, University Center of Northern Espírito Santo, Federal University of Espírito Santo (CEUNES/UFES), where it was washed in a $500 \mu \mathrm{m}$ sieve. After this procedure, the samples were sorted in a stereomicroscope (Leica EZ4), and the polychaetes were separated and preserved in $70 \%$ alcohol. Taxonomic identification was based on the morphological characters visualized using an optical microscope (Olympus CX31). 
Samplings were realized under license granted by the Biodiversity Information and Authorization System (SISBio No. 23658-1), issued by Ministry of Environment (MMA), Chico Mendes Institute for Biodiversity Conservation (ICMBio).

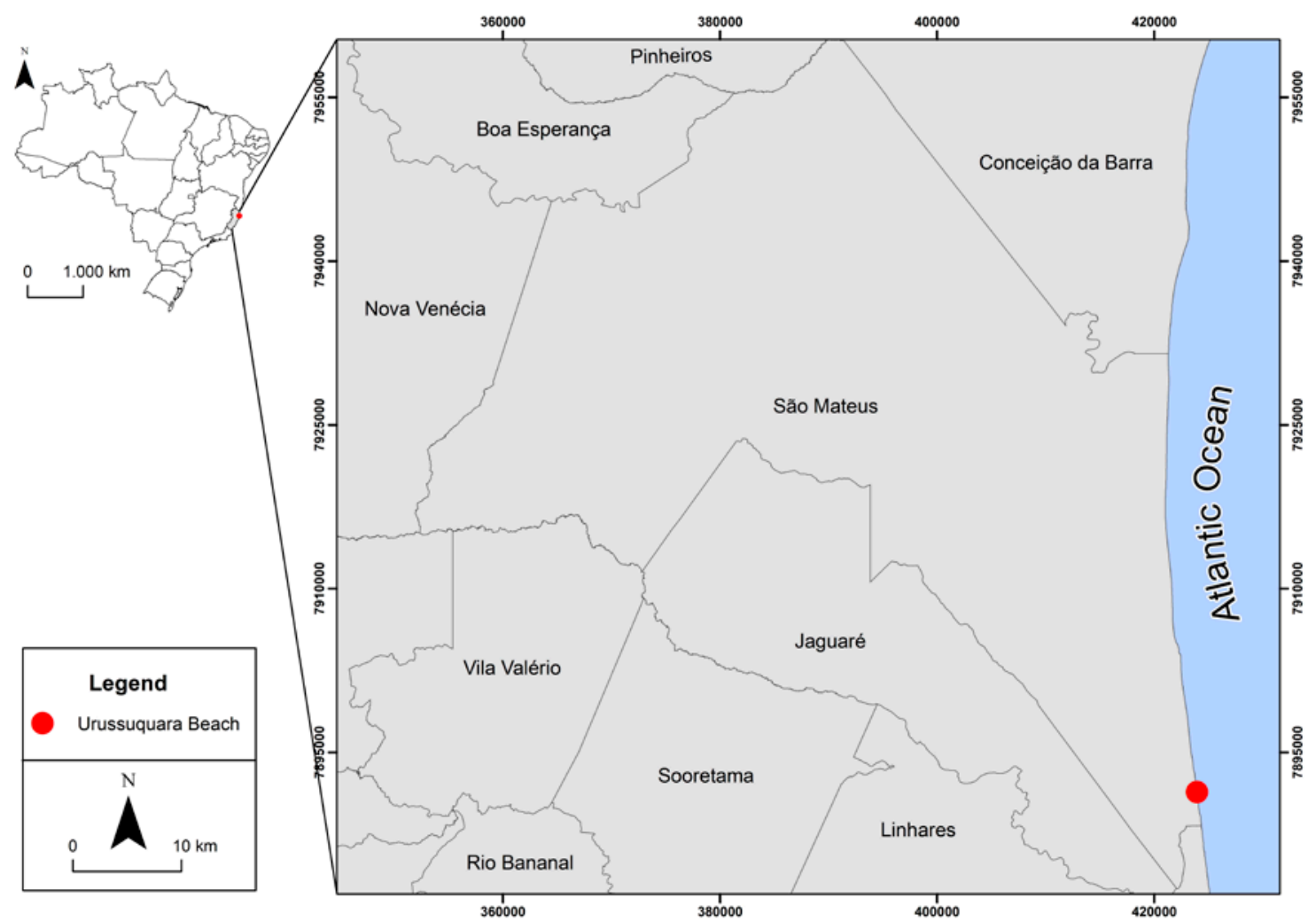

Figure 1. Map of the study area in Espírito Santo State, Southeastern Brazil. Polychaetes were collected at a sandstone reef in the Urussuquara Beach.

\section{Results}

We sampled a total of 1,395 individuals (Table 1) distributed in 36 taxa, of which the most abundant were Phragmatopoma caudata (Sabellariidae) (31\%), followed by Marphysa sanguinea (Eunicidae) (16\%), Perinereis anderssoni (Nereididae) (8\%), Perinereis spp. (Nereididae) (8\%), Syllidae type $1(7 \%)$, and Alitta succinea (Nereididae) (6\%).
The other 30 taxa found were very low in abundance (below $5 \%$ each). In the three months of sampling, the lower intertidal always presented the greatest abundance of species. Our study also contributes with new records of four genus for the Espírito Santo State, Notomastus, Hemipodus, Lysarete, Proceraea and a new species of Syllidae, which is currently under description. 
Table 1. Taxa found in the middle intertidal region of sandstone reef in the Urussuquara Beach.

\begin{tabular}{|c|c|c|c|c|c|c|c|c|c|}
\hline \multirow{2}{*}{ Taxon } & \multicolumn{3}{|c|}{ August/2010 } & \multicolumn{3}{|c|}{ February/2011 } & \multicolumn{3}{|c|}{ August/2011 } \\
\hline & UI & MI & LI & UI & MI & LI & UI & MI & LI \\
\hline \multicolumn{10}{|l|}{ Capitellidae Grube, 1862} \\
\hline Capitella sp. Blainville, 1828 & 1 & 5 & 0 & 4 & 8 & 2 & 1 & 0 & 1 \\
\hline Notomastus sp. M. Sars, $1851^{*}$ & 0 & 0 & 0 & 0 & 0 & 0 & 1 & 0 & 1 \\
\hline \multicolumn{10}{|l|}{ Eunicidae Berthold, 1827} \\
\hline Eunice sp. Cuvier, 1817 & 0 & 0 & 0 & 0 & 0 & 0 & 0 & 3 & 0 \\
\hline Lysidice sp. Lamarck, 1818 & 0 & 0 & 2 & 1 & 0 & 1 & 1 & 0 & 0 \\
\hline $\begin{array}{l}\text { Marphysa sanguinea Quatrafages, } \\
1866\end{array}$ & 29 & 39 & 1 & 32 & 68 & 6 & 35 & 9 & 6 \\
\hline \multicolumn{10}{|l|}{ Glyceridae Grube, 1850} \\
\hline Hemipodus sp. Quatrafages, $1866^{*}$ & 0 & 0 & 0 & 0 & 0 & 0 & 0 & 1 & 0 \\
\hline \multicolumn{10}{|l|}{ Goniadidae Kinberg, 1866} \\
\hline Undetermined Goniadidae & 0 & 1 & 1 & 0 & 0 & 0 & 0 & 0 & 0 \\
\hline \multicolumn{10}{|l|}{ Nerididae Blainville, 1818} \\
\hline Undetermined Nereidae & 2 & 3 & 0 & 0 & 2 & 0 & 1 & 0 & 1 \\
\hline Laeonereis culveri (Webster, 1879) & 0 & 0 & 0 & 0 & 0 & 0 & 0 & 0 & 2 \\
\hline Neanthes sp. (Leuckart, 1847) & 0 & 0 & 0 & 0 & 0 & 0 & 0 & 0 & 8 \\
\hline Alitta succinea (Leuckart, 1847) & 1 & 3 & 2 & 24 & 8 & 41 & 2 & 3 & 6 \\
\hline Nereis sp. Linnaeus, 1758 & 0 & 0 & 0 & 0 & 0 & 0 & 0 & 0 & 5 \\
\hline $\begin{array}{l}\text { Nereis broa Lana and Sovierzovsky, } \\
1987\end{array}$ & 0 & 1 & 3 & 0 & 0 & 0 & 0 & 1 & 2 \\
\hline Nereis riisei Nereis, 1857 & 2 & 0 & 0 & 0 & 0 & 0 & 0 & 3 & 6 \\
\hline Perinereis spp. (Grube, 1840) & 4 & 10 & 0 & 19 & 56 & 19 & 0 & 2 & 0 \\
\hline Perinereis anderssoni Kinberg, 1866 & 2 & 7 & 18 & 3 & 9 & 6 & 21 & 2 & 44 \\
\hline Perinereis cultrifera (Grube, 1840) & 0 & 0 & 0 & 0 & & 2 & 0 & 0 & 3 \\
\hline Perinereis ponteni Kinberg, 1866 & 7 & 2 & 0 & 2 & 4 & 56 & 0 & 0 & 5 \\
\hline \multicolumn{10}{|l|}{ Lumbrineridae Schamarda, 1861} \\
\hline Lysarete sp. Kinberg, 1865* & 9 & 0 & 0 & 0 & 0 & 0 & 0 & 0 & 0 \\
\hline \multicolumn{10}{|l|}{ Sabellariidae Johnston, 1865} \\
\hline $\begin{array}{l}\text { Phragmatopoma caudata Krøyer in } \\
\text { Mörch, } 1846\end{array}$ & 5 & 14 & 17 & 6 & 302 & 78 & 0 & 0 & 7 \\
\hline \multicolumn{10}{|l|}{ Terebellidae Johnston, 1846} \\
\hline Undetermined Terebellidae & 18 & 1 & 0 & 0 & 0 & 0 & 0 & 0 & 0 \\
\hline \multicolumn{10}{|l|}{ Syllidae Grube, 1850} \\
\hline Proceraea spp. Langerhans, $1884^{*}$ & 1 & 0 & 0 & 0 & 0 & 0 & 0 & 0 & 0 \\
\hline Syllis cf. magellanica Augener, 1918 & 13 & 16 & 0 & 0 & 22 & 0 & 21 & 0 & 2 \\
\hline $\begin{array}{l}\text { Syllis pseudoarmillaris Nogueira and } \\
\text { San Martin, } 2002\end{array}$ & 6 & 0 & 0 & 0 & 0 & 0 & 9 & 0 & 0 \\
\hline Syllis sp. 2 Savigny in Lamarck, 1818 & 0 & 0 & 1 & 0 & 0 & 0 & 0 & 0 & 2 \\
\hline Syllidae Type 1 & 6 & 46 & 3 & 15 & 15 & 4 & 2 & 5 & 2 \\
\hline Syllidae Type 2 & 16 & 0 & 0 & 15 & 0 & 0 & 0 & 1 & 0 \\
\hline Syllidae Type 3 & 0 & 1 & 0 & 0 & 0 & 0 & 0 & 0 & 0 \\
\hline Syllidae Type 4 & 0 & 0 & 0 & 0 & 0 & 19 & 0 & 0 & 0 \\
\hline $\begin{array}{l}\text { Sipuncula Stephen and Edmond } \\
(1972)\end{array}$ & 3 & 0 & 0 & 0 & 3 & 0 & 2 & 0 & 0 \\
\hline
\end{tabular}

$\mathrm{UI}=$ upper intertidal; $\mathrm{LI}=$ lower intertidal; $\mathrm{MI}=$ middle intertidal. $\left({ }^{*}\right.$ ) Indicate new records for the Espírito Santo State, Southeastern Brazil. 


\section{Discussion}

The most abundant species of this study are common to other studies on consolidated substrates (Amaral et al., 2013). For example, Phragmatopoma caudata (the most abundant), is a gregarious Sabellaridae ecologically relevant in the construction of biogenic reefs what contribute to increase diversity and protect coasts (Goldberg, 2013; Nunes et al., 2017). In Brazil, there are records of Phragmatopoma caudata along the coast, from the Piauí State in the Northeast (Gomes-Filho et al., 2017) to the Rio Grande do Sul State in the South of the country (Kirtley, 1994; Lana and Bremec, 1994; Pagliosa et al., 2014).

The second most abundant species, Marphysa sanguinea, is a common eunicid, globally distributed on consolidated and unconsolidated substrates of different marine environments, especially in sheltered places (Li et al., 2014). Species of Eunicidae are commercially used in aquaculture as food for fishes and shrimps (Fidalgo e Costa et al., 2016) and as bait in recreational fishing (Zanol et al., 2016).

Regarding species of Nereididae, Perinereis anderssoni and other species of the genus Perinereis are widely distributed along the Western Atlantic, occurring mainly on rocky shores (Santos and Steiner, 2006; Peixoto and Santos, 2016). Perinereis spp. and Alitta succinea can be easily found in shallow waters (Coutinho and Santos, 2014).

Species of Syllidae are very abundant and diverse in benthic marine habitats and are especially common on hard substrates, where they display an erratic lifestyle between algae and rock crevices. The taxonomic identification at a specific level can be hampered by the small size of the individuals and by the absence of studies with taxonomic keys and detailed descriptions (San Martín and Worsfold, 2015). Both Nereididae and Syllidae are families of common predatory species in the intertidal (Barroso et al., 2017; Chatzigeorgiou et al., 2017).

This study consists of the first inventory of polychaetes of the Urussuquara Beach and represents the first step to fill the knowledge gap on sandstone reefs in Southeastern Brazil and on the Espírito Santo State. Our work records for the first time the genus Notomastus (Capitellidae), Hemipodus (Glyceridae), Lysarete (Lumbrineridae), Proceraea (Syllidae) and a new species of Syllidae that is currently under description (Paresque et al., in prep.) (Table 1).

In addition, it is worth mentioning that the environment studied here may suffer eminent extinctions, since it is planned for January 2019 to build a large development of Odebrecht and Petrocity Portos, the São Mateus Port Center. The impacts caused by such a large building reinforce that environmental degradation remains the greatest threat to coastal and marine regions and that the biodiversity crisis is widespread because species are being extinguished at a rate higher than described. Studies such as this one are relevant efforts to prevent or draw attention to it.

\section{Conclusions}

This work contributes to the dissemination of the diversity of Espírito Santo State polychaetes, registering four new genus for the state and providing the first inventory for Urussuquara Beach, a place that will suffer from the impacts of the construction of a Port next year. We hope that this work will contribute as a useful basis for the future elaboration of management and conservation plans for this environment. 


\section{Acknowledge}

We thank the Federal University of Espírito Santo for all the support during the execution of this study.

\section{Conflict of interests}

The authors declare that they have no conflict of interests.

\section{References}

Amaral, A. C. Z.; Jablonski, S. Conservação da biodiversidade marinha e costeira no Brasil. Megadiversidade, v. 1, no. 1, p. 43-51, 2005.

Amaral, A. C. Z.; Nallin, S. A. H.; Steiner, T. M.; Forroni, T. O.; Gomes, D. F. Catálogo das espécies de Annelida Polychaeta do Brasil. Campinas: Editora da Unicamp, 2013.

Barroso, R.; Paiva, P. C.; Nogueira, J. M. M.; Fukuda, M. V. Deep sea Syllidae (Annelida, Phyllodocida) from Southwestern Atlantic. Zootaxa, v. 4221, no. 4, p. 401-430, 2017. https://doi.org/10.11646/zootaxa.4221.4.1

Chatzigeorgiou, G.; Keklikoglou, K.; Faulwetter, S.; Badalamenti, F.; Kitsos, M. S. Arvanitidis, C. Midlittoral polychaete communities in the Eastern Mediterranean Sea: New information from the implementation of the Natural Geography in Shore Areas (NaGISA) protocol and comparisons at local and regional scales. Marine Ecology, v. 38, no. 1, e12339, 2017. https://doi.org/10.1111/maec.12339

Correia, M. D. Recifes. In: Correia M. D.; Sovierzoski, H. H. (Eds.). Ecossistemas marinhos: recifes, praias e manguezais. Maceió: Edufal, 2005. p. 13-18.

Correia, M. D. Scleractinian corals (Cnidaria: Anthozoa) from reef ecosystems on the Alagoas Coast, Brazil. Journal of the Marine Biological Association of the United Kingdom, v. 91, no. 3, p.659-668, 2010. https://doi.org/10.1017/s00253154100008 58

Correia, M. D.; Sovierzoski H. H. Ecossistemas costeiros de Alagoas, Brasil. Rio de Janeiro: Technical Books, 2009.

Costa, K. G.; Nalesso, R. C. Effects of mussel farming on macrobenthic community structure in Southeastern Brazil. International Aquatic Research, v. 258, no. $1 / 4$, p. $655-663,2006$. https://doi.org/ 10.1016/j.aquaculture.2006.04.023

Coutinho, M. C. L.; Santos, C. S. G. Morphological anomalies in polychaetes: Perinereis anderssoni (Polychaeta: Annelida) examples from the Brazilian coast. Memoirs of the National Museum, v. 71, p. 45-51, 2014. https://doi.org/10.24199/j.mmv.2014. 71.05

Coutinho, R. Bentos de costões rochosos. In: Pereira, R. C.; Soares-Gomes, A. (Eds.). Biologia Marinha Rio de Janeiro: Interciência, 2002. p. 281-298.

D’Alessandro, M.; Romeo, T.; Castriota, L.; Cosentino, A.; Perzia, P.; Martins, R. New records of Lumbrineridae (Annelida: Polychaeta) in the Mediterranean Biogeographic Province, with an update taxonomic key. Italian Journal of Zoology, v. 83, no. 2, p. 233-243, 2016. https://doi.org/10.1080/11250003.2016.11 54615

Edgar, G. J. The ecology of South-East Tasmania phytal animal communities. I. Spatial organization on a local scale. Journal Experimental Marine Biology and Ecology, v. 70, p.129-157, 1983. https://doi.org/ 10.1016/0022-0981(83)90090-4

Fidalgo e Costa, P.; Sá, E.; Alves, A. S.; Cabral, S.; Castro, N.; Picard, D.; Castro, J. J.; Fonseca, L. C.; Chainho, P.; Canning-Clode, J.; Pombo, A. M.; Costa, J. L. Anelídeos poliquetas como isco vivo: caracterização da atividade de apanha e ambientes salobros costeiros portugueses. In: Fonseca, L. C.; Garcia, A. C.; Pereira, S. D.; Rodrigues, M.A.C. (Eds.). Entre rios e mares: um patrimônio de ambientes, história e saberes. Rio de Janeiro: Braspor, 2016. p. 33-43.

Gao, K.; McKinley, K. R. Use of macroalgae for marine biomass production and $\mathrm{CO}_{2}$ remediation: A review. Journal of Applied Phycology, v. 6, no. 1, p. 45-60, 1994. https://doi.org/10.1007/BF02185904

Giere, O. Meiobenthology: The microscopic motile fauna of aquatic sediments. Berlim: Springer-Verlag, 2009.

Goldberg, W. M. The biology of reefs and reef organisms. Chicago: University of Chicago Press, 2013.

Gomes-Filho, J. G. F.; Santos, M. V. B. Q.; Souza, R. A. First record of Phragmatopoma caudata Krøyer in Mörch, 1863 (Annelida, Sabellariidae) in the State of Piauí, Northern Brazilian coast: Westernmost record in 
Brazil. Check List, v. 13, no. 4, p. 343-348, 2017. https://doi.org/10.15560/13.4.343

Kirtley, D. W. A review and taxonomic revision of the Family Sabellariidae Johnston 1865 (Annelida: Polychaeta). Vero Beach: Sabecon Press, 1994.

Lana, P. C.; Bremec, C. Sabellariidae (Annelida: Polychaeta) from South America. Annales du Muséum d'Histoire Naturelle, v. 162, p. 211-222, 1994.

Li, S.; Chen, Y.; Zhang, M.; Bao, X.; Li, Y.; Teng, W.; Liu, Z.; Fu, C.; Wang, Q.; Liu, W. Complete mitochondrial genome of the marine polychaete, Marphysa sanguinea (Polychaeta, Eunicida). DNA Mitochondria, v. 27, no. 1, p. 42-43, 2014. https://doi.org/10.3109/ 19401736.2013.869686

Maia, L. P.; Cavalcante, M. D. Zoneamento Ecológico e Econômico da Zona Costeira do Estado do Ceará (ZEE-CE). In: Mapeamento das unidades geoambientais da zona costeira do Estado do Ceará. Fortaleza: Governo do Estado do Ceará, Superintendência Estadual do Meio Ambiente, 2005.

Masunari, S. Ecologia das comunidades fitais. Anais do Simpósio de Ecossistemas da Costa Sul e Sudeste Brasileira, Cananéia, Academia de Ciências do Estado de São Paulo, p. 195-233, 1987.

Nalesso, R. C.; Joyeux, J.-C.; Quintana, C. O.; Torezani, E.; Otegui, A. C. P. Soft-bottom macrobenthic communities of Vitoria Bay Estuarine System, Southeastern Brazil. Brazilian Journal of Oceanography, v. 53, p. 23-38, 2005. https://doi.org/10.1590/ S1679-87592005000100003

Nascimento, E.; Rosso, S. Fauna associada à macroalgas marinhas bentônicas (Rhodophyta e Phaeohyta) da Região de São Sebastião, São Paulo. Brazilian Journal of Ecology, v. 11, no. 1/2, p. 38-51, 2007.

Nunes, F. L. D.; Wormhoudt, A. V.; FaroniPerez, L.; Fournier, J. Phylogeography of the reef-building polychaetes of the genus Phragmatopoma in the Western Atlantic Region. Journal of Biogeography, v. 44, no. 7, p.1612-1625, 2016. https://doi.org/ 10.1111/jbi.12938

Nybakken, J. W.; Bertness, M. D. Marine biology: An ecological approach. San Francisco: Benjamin Cummings, 2004.

Padula, V.; Bahia, J.; Correia, M. D.; Sovierzoski, H.H. New records of opisthobranchs (Mollusca: Gastropoda) from Alagoas, Northeastern Brazil. Marine Biodiversity Records, v. 5, e57, 2012. https://doi.org/10.1017/s17552672120003 46

Pagliosa, P. R.; Doria, J. G.; Misturini, D.; Otegui, M. B. P.; Oortman, M. S.; Weis, W. A.; Faroni-Perez, L.; Alves, A. P.; Camargo, M. G.; Amaral, A. C. Z.; Marques, A. C.; Lana, P. C. NONATObase: a database for Polychaeta (Annelida) from the Southwestern Atlantic Ocean. Database, v. 2014, p. 1-49, 2014. https://doi.org/10.1093/database/bau002

Paresque, K.; Scamparle, N. M. A new species of Syllis (Annelida: Syllidae) with Y-shaped simple chaetae from an area affected by the Samarco mine tailing disaster - worst Brazilian environmental disaster. (In preparation).

Peixoto, A. J. M.; Santos, C. S. G. Reproductive biology of Perinereis anderssoni (Polychaeta: Nereididae) in a subtropical Atlantic Beach. Invertebrate Reproduction \& Development, v. 60, no. 3, p. 201-211, 2016. https://doi.org/10.1080/07924259.2016.11 94333

Rabelo, E. F.; Soares, M. O.; Bezerra, L. E. A.; Matthews-Cascon, H. Distribution pattern of zoanthids (Cnidaria: Zoantharia) on a tropical reef. Marine Biology Research, v. 11, no. 6, p.584-592, 2015. https://doi.org/10.1080/17451000.2014.96 2542

Rouse, G.; Pleijel, F. Polychaetes. New York: Oxford University Press, 2001.

Sá, F. S.; Nalesso, R. C.; Paresque, K. Fouling organisms on Perna perna mussel: is it worth to remove them? Brazilian Journal of Oceanography, v. 55 , no. 2 , p. 155-161, $2007 . \quad$ https://doi.org/10.1590/S167987592007000200008

San Martín, G.; Worsfold, T. M. Guide and keys for the identification of Syllidae (Annelida, Phyllodocida) from the British Isles (reported and expected species). ZooKeys, v. 488, p. 1-29, 2015. https://doi.org/ 10.3897/zookeys.488.9061

Santos, C. S. G.; Steiner, T. M. Família Nereididae. In: Amaral, A. C. Z.; Rizzo, A. E.; Arruda, E. P. (Eds.). Manual de Identificação de Invertebrados Marinhos da Região Sudeste-Sul do Brasil. São Paulo: Editora USP, 2006. p. 121-133.

Sönmez, S.; Sak, S.; Karaytuğ, S. Marine interstitial and phytal Miraciidae Dana, 1846 
(Crustacea: Copepoda: Harpacticoida) inhabiting along the Mediolittoral Zone of Turkish Coasts. Journal of Anatolian Natural Sciences, v. 5, no. 1, p. 52-87, 2014.

Spalding, M.; Taylor, M.; Ravilious, C.; Short, F.; Green, F. Global overview. The distribution and status of seagrasses. In: Green, E. P.; Short, F. T.; Spalding, M. D. (Eds.). World atlas of seagrasses: Present status and future conservation. Berkeley: University of California Press, 2003. p. 5-26.

Zanol, J.; Silva, T. S. C.; Hutchings, P. Marphysa (Eunicidae, polychaete, Annelida) species of the Sanguinea group from Australia, with comments on pseudo-cryptic species. Invertebrate Biology, v. 135, no. 4, p. 328-344, 2016. https://doi.org/10.1111/ ivb. 12146 (CC) Attribution, que permite uso irrestrito, distribuição e reprodução em qualquer meio, desce que a obra original seja devidamente citada. 